\title{
TEACHING THE VIOLENT PAST IN SECONDARY SCHOOLS IN NEWLY INDEPENDENT SOUTH SUDAN
}

\section{Merethe Skårås}

Oslo and Akershus University College

Email: merethe.skaras@hioa.no

\section{Anders Breidlid}

Oslo and Akershus University College

Email: Anders.Breidlid@hioa.no

\section{ABSTRACT}

This article analyses the teaching and learning of South Sudan history from 1955-2005 in secondary schools in South Sudan with a specific focus on national unity. The article draws on two periods of focused ethnography, from September to December 2014 and July to September 2015, including classroom observation and interviews with teachers, student teachers and students in two geographical locations. Additionally, 69 written essays from secondary school students of History have been analysed in order to get an insight into their knowledge of the recent violent past. The use of classroom video observation makes a significant contribution to the field as most studies focus on documents and textbooks. The analysis focuses on national unity and uses theories of collective memory and attribution to examine the narratives of the past. The article argues that the national narrative of South Sudan is still closely tied to enemy images of the former enemy of Sudan in the north, while internal ethnic tensions are suppressed and excluded from the official national narrative taught in the classroom.

Keywords: Sudan; South Sudan; History education; focused ethnography; attribution theory; collective memory; civil wars

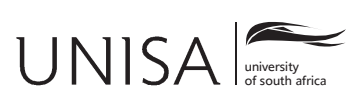

Education as Change

Volume 20 | Number 3 | 2016 | pp. 98-118

www.educationaschange.co.za
DOI: http://dx.doi.org/10.17159/1947-9417/2016/1312 Print ISSN 1682-3206 | Online 1947-9417

(C) 2016 The Author(s) 


\section{INTRODUCTION}

Internationally there is a growing body of research within the field of History education, particularly in societies divided by lines of ethnicity, religion, language or culture (Baranović, Jokić \& Doolan 2007; Cole 2007; Davies 2003; Freedman et al. 2008; Weldon 2010). In societies emerging from violent conflict, History education is often contested and emotional. Although significant contributions have been made within the field, most studies focus on documents and textbooks (Dorschner \& Sherlock 2007; Korostelina 2008; Pingel 2008). While textbooks often take long to rewrite and publish and even though textbooks are revised, they are often not available and used in the classrooms. Therefore there is a need for classroom studies of the teaching and learning of History in divided societies in order to examine classroom practices. Pointing to the important role of the teacher in the classroom, Weldon (2010) argues that change at the classroom level that is decisive is the most difficult to achieve for newly emerging societies. After decades of war, South Sudan has prioritised History education related to nation building efforts in secondary school. According to the curriculum, one of the general objectives for the subject is to "develop the sense of nationalism, patriotism and national unity' (Government of Southern Sudan 2007, 169). Research shows that the resistance towards the north and the fight for liberation united southerners across ethnic lines (Breidlid 2005) even though internal rivalry has always existed within the south (Hutchinson \& Pendle 2015; Breidlid, Breidlid \& Said 2014). However, in newly independent South Sudan the fight for national liberation is over and currently internal ethnic tensions are prominent in all areas of society. There is a struggle for power at the top political level and ethnic groups and personalities are in constant conflict with each other. In addition to this, the syllabus does not provide information that helps the teacher to interpret events that can be conveyed to the students in a meaningful way. This limitation in the syllabus is one of the core arguments why this article focuses on the teaching and learning of the violent past in South Sudan (1955-2005) in secondary schools and the potential of the subject of History for fostering national unity.

The article first gives a brief introduction to the historical background of South Sudan. After this overview, we outline the theoretical framework combined with current research within the field of History education in divided societies. Subsequently, the main methods within this focused ethnography are explained before the findings are presented. Towards the end of the article, the findings are discussed within the theoretical framework before making some concluding remarks.

\section{EDUCATION AND CONFLICT IN SOUTH SUDAN}

South Sudan gained independence on 9 July 2011 after decades of civil war. Since 1955 and until the signing of the Comprehensive Peace Agreement (CPA) in 2005 Sudan experienced a civil war between the north and the south, interrupted only by a peaceful period between 1972 and 1983, thus making it the longest civil war on the African 
continent (Johnson 2003). Since independence from the Anglo-Egyptian condominium rule in 1956, the Muslim Arabs have controlled the state apparatus in the country, except in the liberated areas in the south, which were controlled by the Sudanese People's Liberation Army (SPLA) (Breidlid 2005) and other armed groups. In 1990, the current president of Sudan, Omar Hassan Ahmad al-Bashir, announced that the education system at all levels should be based on Islamic values (Breidlid 2005, 251). This led to Arabic as the sole language of instruction in the schools and as Sommers (2005, 16) argues 'school was no longer a refuge from conflict but rather a place to express resistance, a place permeated by a sense of subjugation and division'. In line with this, Oyenak (2006) argues, based on an analysis of 41 textbooks in English and Arabic produced by the National Curriculum Centre in Khartoum, that the Arab-Muslim bias is overwhelming and that South Sudanese history has been almost completely left out of the textbooks.

The south's secession and independence in 2011, following the signing of the CPA in 2005, marked a new era where South Sudan as an independent state could implement its own educational policies. However, on 15 December 2013 a new conflict broke out between different factions within the main political party in South Sudan, the SPLM. This conflict, which started as a struggle for power, soon developed into an ethnic conflict between the two major ethnic groups in South Sudan. The largest group was led by Salva Kiir, president of the Republic of South Sudan and Dinka by ethnicity, and the SPLM/A in opposition was led by Riek Machar (former vice president) who is from the second largest ethnic group in South Sudan, the Nuer. The Nuer and the Dinka are only two of the 64 ethnic groups in South Sudan and they are both Nilotic pastoralist groups, which means they are semi-nomadic cattle keepers. However, among all the ethnic groups, there are no clear lines of who allies with whom and the political situation is complex with different factions fighting each other in the quest for power. In August 2015 Riek Machar and Salva Kiir signed a Compromised Peace Agreement (CPA2) after massive international political pressure. However, both parties have committed violations of the agreement. In April 2016, Riek Machar returned to Juba and was sworn in as the first vice president in a transitional government of national unity formed by four factions of South Sudan's former warring parties and political rivals (Sudan Tribune 2016a). The CPA2 has not been implemented and in the days leading up to the fifth anniversary of the independence, 9 July 2016, severe conflict broke out in Juba. Hundreds of people were killed and tens of thousands displaced (Sudan Tribune 2016b). The conflict has turned into another civil war.

The conflict with its ethnic dimensions has enormous consequences for development in the country, and also for education. There is a huge lack of teachers and government teachers are not being paid on a regular basis (informal conversations). Due to the very unstable situation both teachers and students enrol and leave school throughout the year with negative consequences for the quality of education. However, even though the quality is poor, the school can potentially be an important site where students from 
various ethnic groups meet and learn together and thus may contribute to promoting unity and understanding across ethnicities and generations.

The Syllabus for Southern Sudan Certificate of Secondary Education from 2007 (Government of Southern Sudan 2007) is the syllabus that was to be implemented in the schools by 2013. However, there is a decreasing number of secondary schools that run according to the South Sudanese syllabus. Several states have not yet implemented the Southern Sudan syllabus of 2007 and since 2014 an increasing number of schools teach according to the old Sudan syllabus that most southerners were forced to use prior to independence. There is no unified curriculum for South Sudan yet and it is difficult for students to understand the messy curriculum situation because some schools use the curricula and syllabi of either Uganda, Kenya, Sudan or Ethiopia (Novelli et al. 2016; Radio-Miraya 2015) 1 .

In recent years there has been a greater understanding of the relationship between education's potential to facilitate peacebuilding and social cohesion (McCully 2009; Davies 2003). This is also reflected in the Syllabus for Southern Sudan Certificate of Secondary Education (Government of Southern Sudan 2007). This syllabus contains a list of national goals for education in general, including that "education shall foster nation building through interaction, peace, self-reliance, patriotism and promoting respect and tolerance for other cultures, traditions, opinions and beliefs' $(2007, \mathrm{i})$. History is seen as one of the main subjects necessary to attain these goals and as Freedman et al. (2008) argue, schools reflect and have the potential to influence the process of collective memory transmission and transformation through History education. In this process, it is crucial to understand the role of teaching History in shaping a new national identity, while also incorporating the social realities of continuing ethnic identities in productive and non-divisive ways (Freedman et al. 2008). But education can also exacerbate conflict (see e.g. Chapman in Cole 2007). As Vriens (2003) argues education is one of 'the most successful instruments for the. . .dissemination of militarism', and Sommers $(2005,8)$ claims that 'many who conduct modern wars are expert at using educational settings to indoctrinate and control children'.

\section{COLLECTIVE MEMORY}

Theories on collective memory and historical memory (Wertsch 2002; Halbwachs 1992) provide an important lens in order to analyse how historical narratives in the classroom are constructed and taught to the students. In analysing data from a fragile conflict-affected country like South Sudan we apply Wertch's (2002) work on collective

1 A revised curriculum for South Sudan was launched in August 2015, however this has not been distributed to the schools and all schools except those mentioned earlier in the article use the syllabus from 2007. 
memory as a theoretical point of departure together with research within the field of History education in societies emerging from violent conflict.

Even though there is some disagreement in the research literature about what collective memory entails, collective memory studies 'tend to focus on how efforts to create a usable past serve political and identity needs...[and is more] a site of active contestation and negotiation than... a means of accurately representing the past' (Wertsch $2002,35)$. In collective memory studies the representation of the past is viewed as being socially constructed and shared by members of a group or institutions (Wertsch 2002; Halbwachs 1992). Wersch (2002) discusses how memory can provide a usable past made or developed for a specific purpose. While collective memory is often employed at the expense of what critics would call historical accuracy, it does not mean that collective memory operates 'without regard to accurate representation of the past' (Wertsch 2002, 35). However, what 'accurate' representation actually entails is very often contested and difficult to agree on. Both collective memory and historical analyses are not stable over time and change on the basis of what the current hegemonic power, usually the government in position, thinks is convenient past knowledge to be conveyed to the next generation. As Nigel Hunt $(2002,530)$ states: 'Memory is an interplay between events, time, society and the individual. Memories are manipulated to fit our life history, our own views about ourselves. They are also manipulated by society, by the ways in which external information is transmitted to us'.

History education is thus a contested field, not the least in conflict situations, because it is not, as Zembylas and Bekerman $(2008,126)$ state, only about whether children should be taught to remember the past, but also about how the past is interpreted. Halbwachs (1992) argues that when a person does not remember events directly, they are stimulated in indirect ways, i.e. by reading or listening or in our case teaching and learning in schools. As a socially constructed phenomenon, collective memory is created in a collective context and in our research the teacher is the main actor in creating the collective memory in the classroom. Historical narratives are constructed by choosing certain significant elements of the history and leaving out others. Thus all historic narratives have an ideological bias, in most cases serving the interests of the hegemonic power, and in rare cases narratives try, without necessarily being approved by the hegemonic power, to represent the history of the Other and nonhegemonic groups. Nations often maintain a dichotomy between 'us' and the Other where 'we' represent and hegemonise what is accepted and 'normal' in the society whereas the Other represents what is alien, and inferior (Said 1995; Breidlid 2013). In many societies, especially those divided through ethno-national conflicts, the subject of History is often used to shape collective identities through a common narrative meant to reinforce a sense of national pride and loyalty and to legitimate political goals. This is done by representing the Other in a negative way by perpetuating negative stereotypes and enmity (Papadakis 2008; Dorschner \& Sherlock 2007). Paulson (2015) refers to this as ethno-nationalist narratives, where narratives construct in-group and out-group 
identities. This is also found in research from Bosnia-Herzegovina (Torsti 2007), Sudan (Breidlid 2010) and Israel/Palestine (Yogev 2012).

In our research it is productive to differentiate between two types of collective memory, i.e. on the one hand collective memory relating to people who have experienced historical events or events which occurred during their lifetime, and on the other hand collective memory relating to events which took place before their lifetime. Those who have experienced specific events in the past seem to have, not unexpectedly, greater authority on the interpretation of these events. This does not, however, mean that their representation is necessarily more accurate, but may serve specific interests and purposes (Wertsch 2002). Clearly collective memory can play a significant role in our definition of ourselves and who we are. It might include values and the distribution of power within or between specific group(s) of society that may either empower people or contribute to feelings of inferiority, exclusion and powerlessness. Leaving out important events as described above does not, as Paulson (2015) argues, easily open up for reconciliatory processes since tensions are swept under the carpet. In certain, rather extreme cases, the exclusion of certain sensitive historical facts can be termed an avoidance strategy. In education it is sometimes applied when dealing with very contentious issues and narratives (Cole 2007; Freedman et al. 2008). As McCully (2009) reminds us, History education in divided societies creates special challenges, especially because history is closely tied to emotions associated with national identity and collective belonging (McCully 2009, 214). The example from Rwanda is a case in point where it is argued that after the genocide in 1994 teachers did not discuss issues of identity. This was partly due to the distortions of a history that the government wished to tell, 'the constraints against teaching students how to be critical thinkers, and, above all, the fear of productive conflict' (Freedman et al. 2008, 684). Avoidance in this example is strongly connected to fear and a possible lack of structures for teachers to handle both the personal and societal legacy of the past (Weldon 2010). Avoidance as a strategy is similar to what Paulson (2015) refers to as exemplary memory where conflict is seen as exception and where the past is used as a guide for action in the present and the future. The focus in such a portrayal of history is on the role of the individual and his/her responsibility for maintaining a culture of peace or conflict whereas causes related to structural inequalities that might have been underlying causes of conflict are underplayed. In our research on South Sudan, we explore to what extent the past in History education is either merely portrayed selectively by leaving out important events or incorrectly by conveying clearly documented false information about past events. The discussion will try to fill gaps in the literature on South Sudan by exploring whether the teaching of History in a South Sudanese context is based on a unified collective memory or whether multiple voices and memories are being presented. 


\section{Attribution theory}

The theory of attribution first originated with Fritz Heider (1958) in his work on causal attributions in the perception of the Other within social psychology. Attribution theory operates with the dual concepts of or the dichotomy between 'dispositional' and 'situational' attributions. While 'dispositional' attributions refer to causality ascribed to internal or more or less innate factors, 'situational' attributions refer to external factors outside the control of the agent (Heider 1958). Related to the narrations of the past in the subject of History, attribution theory is closely connected to the literature about ethnonationalist narratives meant to create self-Other dichotomies. Since Heider's early work the theory has been developed and used within the field of international relations, e.g. relating to the Arab-Israeli conflict (Heradstveit 1979) and Arab images of the Gulf war (Heradstveit \& Bonham 1996). Heradstveit (1979) builds on Heider $(1958,23)$ when he describes how the theory 'specifies the conditions under which behavior is seen as caused by the person performing the action, or by environmental influences and constraints'. In international relations and specifically in the study of conflict, attributions might be treated as attributions of a group rather than of individual persons. Breidlid (2013) uses attribution theory when he describes how the discourses in Sudan and South Sudan were used to harmonise one's own group's position and demonise and homogenise that of the enemy. Related to the complex context of the conflicts in Sudan and within South Sudan, attribution theory is used also in Breidlid (2010) as a theoretical tool to gain deeper insight into the relationship between the different parties in the conflicts and how narratives of the former enemy are constructed and transmitted in the classroom in South Sudan as well to the different ethnic groups within the south.

\section{METHODS}

This article draws on data from a $\mathrm{PhD}$ project on teaching History in newly independent South Sudan that includes two periods of focused ethnographic fieldwork undertaken by the first author and a small research team. ${ }^{2}$ The first period ranged from September to December 2014 (Skårås 2016) and the second from July to September 2015. While ethnography is defined as a method where the researcher participates in a social setting for an extended period of time (Bryman 2004; Cohen, Manion \& Morrison 2011; Hammersley \& Atkinson 1995), focused ethnography intensifies the data collection over a short-time period. This approach often uses multiple research methods, audiovisual technologies and multiple research teams (Knoblauch 2005; Millen 2000; Pink \& Morgan 2013). In conflict settings with limited access and security, focused ethnography is specifically well suited to get an in-depth understanding of phenomena for teaching and learning in schools.

2 Three local research assistants and one Norwegian aid worker residing in Narus for several years. 
This article is specifically informed by qualitative interviews with 17 teachers and 28 students, video classroom observation of eight History lessons and 69 written student essays from six secondary schools in Narus and Juba. Additionally, informal conversations with representatives from the Ministry of Education, headmasters, teachers, parents and students are included. All accessible secondary schools in either the capital Juba in Central Equatoria state or Narus in Eastern Equatoria state that offer History as a subject were selected. This meant that the schools offered the subject of History in English, which all schools that operate according to the South Sudan syllabus do. All History teachers from the respective schools were approached for interviews, however a few never showed up for unknown reasons. The students were students of History in the respective schools and were selected from second-year classes where classroom observation was done. ${ }^{3}$ Convenience sampling was carried out since any student who had time and wanted to contribute to the study for an interview was selected. The 69 student essays were written by students of History from both geographical locations and their participation was voluntary and arranged as an essay writing contest. The essays were written at home during the second period of fieldwork in 2015 and the contest was presented in class and explained by the first author and a research assistant. Also, the criteria for a successful essay were presented by the researchers and the teachers were deliberately left out of this process in order to limit their power to influence the results. The essay question asked the students to 'make an interview with your grandparents or parents about the second civil war (1983-2005). What were the causes of the war? What role did your grandparents or parents play?'. We believe these essays together with interviews and observations give us an indication of both types of collective memory. One type refers to the older generation who have experienced the historical events. The other type of collective memory refers to the retelling or transmitting of the events by the younger generation who have not witnessed the events themselves.

The two geographical locations were chosen due to their accessibility and the research team's prior knowledge of the areas. A large number of internally displaced people reside in the two locations due to the relative stable military situation at the times of fieldwork, and therefore they have a diverse student and teacher population in terms of ethnicity and geographical belonging. We ensured that there were participants from both Nuer and Dinka ethnic groups in the sample together with a number of other ethnic groups. ${ }^{4}$ However, we do not know the exact number of the various ethnic groups since most informants were not identified by ethnicity.

During the research period, the Ministry of Education had not provided teachers or students with textbooks for History. Our research team provided one History textbook, A Concise History of South Sudan (Breidlid, Breidlid \& Said 2014), to each of the

3 This is the year where the Syllabus for Southern Sudan Certificate of Secondary Education covers the recent history of South Sudan from 1956 to the CPA in 2005.

4 Bari, Madi, Nubian, Lotuko, Toposa, Murle, Shilluk and Didinga. 
two schools in Narus before the fieldwork period. However, due to the general lack of teaching materials, the teacher was the main medium through which the curriculum spoke to the students. Therefore, classroom video observation was carried out in four of the six schools, including one teacher in each of these schools. Informed consent was given by both the school and the four teachers and the video observation did not include the students. In the remaining two schools video data was not collected due to one teacher's unwillingness to participate and the very chaotic set up of the last school.

All data was transcribed and imported into NVivo. We used open coding across data sources and generated preliminary codes inductively from the data, with a focus on unity and narratives of the past. In a second round of coding smaller codes collapsed into larger codes with reference to theory and specifically to the central concepts of enemy images and descriptions of 'the Other'. The video data also informed us on the use of notes and teaching aids during lectures.

Specific ethical considerations were taken in this study related to the ongoing conflict in South Sudan. First of all, all participants were given pseudonyms. Second, gender and geographical belonging of individuals are not identified in the published material in order to ensure anonymity. Lastly, all informants gave informed consent and volunteered to participate. ${ }^{5}$ The criterion of voluntarism was treated with the utmost sensitivity due to both culture and the presence of conflict.

We have yet to experience a South Sudanese refuse to take part in research or help out in any way. However, paradoxically enough, we often experienced some people not showing up or postponing appointments and presenting excuses as to why they could not make our appointments. On several occasions this was interpreted and accepted as an unwillingness to participate for unknown reasons. In some cases students were allowed to bring a friend to the interview. We interviewed students in the breaks in between classes in order not to make them miss valuable teaching time and to ensure the students' safety as they could leave school immediately after class time with their friends. In some cases the ethnicity of informants required a different location for the interview, different questions or a different structure for the interview. In some of these cases more informal conversations without a tape recorder worked better. Through several informal conversations with informants we were told that 'we are all traumatised' due to decades of suffering and civil wars. Some students shared horrible testimonies from the previous war in Juba (2013), which made the scope of the interview less important than comforting the student and being an adult listener in order to decrease chances of traumatisation.

5 Approved by Norwegian Social Science Data Services (NSD). 


\section{NARRATIVES OF THE PAST AMONG TEACHERS AND STUDENTS: A CASE OF COLLECTIVE MEMORY?}

When analysing the lessons and to what extent the teaching and learning of the violent past have the potential of fostering national unity there is a need to provide context by examining the content requirements of History listed in the Syllabus for Southern Sudan Certificate of Secondary Education (Government of Southern Sudan 2007). The syllabus briefly presents a list of important events and personalities together with three specific objectives. These objectives ask students to: a) Describe the causes obstacles and effects of given armed struggles in Southern Sudan during the period (1955-2005); b) Name the major personalities during the struggle of the Southern Sudanese and their contributions; and c) State the contribution of the major personalities in the political and armed struggle (Government of Southern Sudan 2007, 172-73).

Since teaching methods and textbooks are beyond the scope of this article, the following section analyses narratives primarily by teachers in the classroom (teaching and what is being observed), interviews with teachers and students and to a lesser extent essays students have written. While the main period covered in the lessons and in the essays was between 1954(55) to 2005, i.e. the conflict between the north and the south, the internal post-independent conflict was also mentioned in some of the interviews and in some student essays. Therefore, the following discussion is divided into two main sections. The first describes 'the Othering of the northerners', the second presents the 'narration of conflicts in the south' which identifies ethnic conflicts within South Sudan both in the past and present.

\section{THE OTHERING OF THE NORTHERNERS}

\section{Teachers' lessons and interviews}

Given the fact that the lessons were heavily influenced by the teachers' lectures, the main focus in this subsection is on how the teachers address the past in lessons and interviews. Most attention is given to the analysis of how the former enemy in the north is narrated or described and to what extent a collective memory lens is productive in understanding the teachers' lessons on the north/south conflict. In line with what others have observed (notably Breidlid 2010) images of the Arabs, northerners and the Khartoum government are portrayed in utterly negative terms, with few if any nuances. During a lesson a teacher explained to his students how:

The war created ill feelings, hatred and distrust between the southerners and Arabs, ok. In the north. This was also one of the effects [of the first civil war]. Even up until today. That ill feelings or hatred or distrust is still existing. Even though we are now two separate countries. Even though we are now two separate countries, ok. That ill feelings, that hatred, that distrust is still existing, ok. Between the southerners and the northerners. Why? Because during the war the Arabs who 
were here in the south killed and mistreated the southerners, ok. So that was the reason why these ill feeling is still there existing today. Good. (Classroom observation, Peter 2015)

Words like hatred and distrust are used to describe the relationship between the people of Sudan in the north and Southern Sudan (now South Sudan). The killings of southerners during the war caused the southerners to attach a specific negative label to the Arabs; and the northerners' atrocities are, understandably enough, a major reason for the ill feelings. The ill feelings that the teacher refers to above are underlined in the way he repeats the negative words and finalises the sentence with 'ok'. This 'ok' might be interpreted as conclusive and beyond discussion. The video transcript shows that the above mentioned quotation is delivered as a monologue to the students with no time for the students to comment or ask questions. The negative images of the Other, the northern enemy, are initially justified in terms of situational attributions, i.e. the causes of the war. The static, negative, one-dimensional images of the Other are repeatedly mentioned by the teachers who describe Arabs as slave traders who ruled southerners and kept them uneducated, and northerners who deceived southerners (Classroom observation, Henry 2015, Peter 2015, Daniel 2015). The Khartoum government is portrayed as the enemy that implemented laws and regulations against South Sudanese values, religion and language. Clearly these negative attributions given to the Arabs and northerners create a usable past for the southerners and serve, in the case of the teacher's narratives, both political and identity needs (in-groups and out-group identities [Paulson 2015]). As one teacher recalls and argues:

...if you learn the way your people suffered and the question you should ask is always: who was responsible for that? Ok. Or who inflicted that suffering on our people. Definitely, the answer is the Arabs and it makes you not to love the Arabs. Yeah. It makes you to look the Arabs as the immediate enemy, the first enemy of South Sudan, you know. (Teacher interview, Robert 2014)

The narratives thus contribute to creating a collective memory where the teacher's stereotypical narrations of the Other go beyond situational attributions and are viewed as clearly dispositional in nature (Heider 1958). The innate nature of the northerners as perceived by the teacher is confirmed in the teacher's narratives of the current situation (post north-south conflict) where animosity towards northerners and Arabs seems undiminished. Often the teacher's narratives connect the past and present by confirming 'that hatred, distrust is still existing' (Classroom observation, Peter 2015). This distrust was also referred to by another teacher who underlined the Arabs' innate, dispositional nature by referring to the distant past: 'because what they did right from the colonial period, before independence. You know. They started actually mistreating South Sudanese before Sudan could gain independence' (Interview, Robert 2014). The Arabs' mistreatment of the southerners was often perceived as more or less independent of the situation on the ground. Collective memory in terms of north-south relations was thus being vigorously upheld. Another teacher explained to his students how the 
northerners decided to deceive the southerners when he described the policies of the northern-based government of Abboud after Sudan's independence:

After that they want to choose a president, a person responsible for them. So they sat together and they decide and choose a person from the northern Sudan. They choose general Ibrahim Abboud to be the first general, to be their leader. When they choose general Ibrahim Abboud, immediately General Ibrahim Abboud decided to come with another different policy in the Sudan. He implemented the Arabization system and Islamization system in both north and south. He forget all about, we know very well that the South Sudan are coming from the product of missionary activities. We received education from the missionaries... and then general Ibrahim Abboud say what? Sunday should be the day of what? The day of work and Friday will be the day of? (Classroom observation, Henry 2015)

The students answered 'rest', after which the teacher confirmed 'rest' and went on to explain how the South Sudanese and their politicians were not happy about this. He further elaborated on the consequences of the policy, saying:

If you do not want to teach the Arabic language in the school you would be put in the prison... If you insist that the Sunday is the day of the rest you will be put in the prison. So, it is like this, it becomes very terrible for the South Sudanese. Immediately most of the South Sudanese politicians will be put where? In the jail, in the prison. And others decided to...form Anyanya ${ }^{6}$ one in the forest. (Classroom observation, Henry 2015)

There is a sense that the teachers in the classroom and in interviews who emphasise the negative images of the Other were not necessarily consciously selective about what they told about the past or were not consciously conveying wrong information. They did not necessarily, as Wertsch $(2002,35)$ states, operate without regard to accurate representation of the past. Most South Sudanese we have spoken to had, however, a very strong self-Other attitude gained through the very long civil war that entailed massive suffering and the loss of two million lives. Stories of atrocities committed by Southern Sudanese or internal, ethnic strife during the war were not highlighted, either because they were not deemed important, because the teachers were ignorant about them, or because they would not disturb an impression of a struggle between Good and Evil, i.e. the southerners' collective memory. Given the current civil war within South Sudan the suppression of internal southern strife in the History teaching, whether consciously done or not, had obviously not had any impact on the issue of unity among southerners - at least not among the warring parties.

6 Anyanya was the first south Sudanese armed resistance movement after the independence of Sudan. 


\section{Students' essays and interviews}

When students wrote about the causes of the war, most of the 69 students provided a list of reasons for the marginalisation of the South Sudanese. Marginalisation and exploitation were mentioned by almost all the students when they gave reasons for the second civil war in South Sudan. The culprits for the war were the elite in the north such as president Nimeiri, president Abboud, the Arab-based Khartoum government, the Arabised north, the northern elite and the Islamist fundamentalists in the north. Moreover, the Khartoum government and their exploitative policies were listed as reasons, such as the imposition of the Sharia law, Arab culture and Islamic religion, the unfavorable redrawing of borders, the lack of development in the south, the lack of access to their own natural resources (water and oil) and a failure to adhere to the Addis Ababa Agreement. As one student wrote: 'the hatred which southerners had against Arab cultural set up, led to this war [the second civil war]' (Student essay, 28). Another student explained how southerners were mistreated by northerners and considered lower class citizens and denied quality education and employment (Student essay, 16a). Clearly collective memory with the stereotypical images of the Arab northerners so prevalent in the lessons was unanimously supported by the students' essays. Thus, no positive images of the Other were identified in the data material. Southern perceptions of the northerners coupled with prejudices and biases of adults are passed on to the next generation, helping to maintain conflictual relations and in fact may reinforce the dynamics of conflict (Dorschner \& Sherlock 2007; Paulson 2015). It is worth noting that the collective memory of the older generation is a source of important knowledge to preserve and pass on to the next generation. Since the older generation has experienced the suffering and participated in the resistance movements, it is to some extent understandable and legitimate that the narratives are emotional and contain onedimensional and stereotypical descriptions of the enemy which they fought against for so many years. The student essays written outside the classroom - often with the help of the older generation - thus reaffirm and sometimes reinforce the lessons from the classroom, solidifying the collective memory of the southerners by drawing a picture of a unified past. The symmetry and unanimity between classroom teaching and lessons learnt outside the classroom is overwhelming. One student underlined that he did not learn from school but from home and that he could ask both his father and grandfather about the war: 'I learn through my father. He was a soldier in Anyanya' (Student essay, 3a). The student concluded by saying that his family was even more educated than the teachers about this topic (Student essay, 3a). This illustrates how narratives learnt outside the classroom might be even more powerful than those learnt in school. In one extreme case a student not only Othered the Arabs on the basis of the conventional collective memory, but distorted the historical facts when she explained what she had learnt in the subject of History so far in secondary school. 
We learn about the coming of the Arabs into Sudan. First of all the Arabs are people who came from Egypt to Sudan. And the reason why they come to Sudan, they heard about the fertile land of the southerners. That is why they come. Because the northerners they do not have a good climate whereby they can cultivate some crop... They also came to Sudan because they heard about the oil in southern Sudan. For example in Bentiu. They came to Sudan because of the minerals, for example the gold in Kapoeta east. They come and attract that gold and take to their place... They come to Sudan also for slave trade. They used southerners for slave trade. They take man and women as their labor and they can kill. They came also, they come and introduce sharia laws to the southerners. If you are Christian they came to change Christian religion. (Interview, student 1E)

This student not only gives an unfavorable image of the Other, the Arabs in the north, but holds wrong information about the reasons why the Arabs came to Sudan. The coming of the Arabs goes far back in history and certainly a long time before the discovery of the oil. However, this narrative might illustrate how historical events that took place before the lifetime of this student have been altered by transmission from one generation to the other. Thus the transmission of narratives across generations creates new narratives of collective memory among the youth in South Sudan.

\section{THE NARRATION OF CONFLICTS WITHIN THE SOUTH}

While hostile images of the Other are drawn of the 'former' enemy in the north by giving the Other dispositional attributions, there is also, in the historical narratives of both teachers and students, Othering of people from ethnic groups inside South Sudan identified in the data material. While enemy images of the Other in the north are found both inside and outside the classroom (in lessons, interviews and essays), narratives including enemy images of ethnic groups within the south are identified only in interviews and some essays.

\section{Teachers' lessons and interviews}

Even though narratives of ethnic tensions and the recent civil war inside the south were not identified during classroom observations they nevertheless existed in the classroom underneath the surface, among both students and teachers. When a student posed a question that required the teacher to touch upon the issue of ethnic tensions within the south, the teacher answered superficially and seemed to avoid the ethnic details (Classroom observation, Stephen 2014, Henry 2015). There was a sense that clashes between ethnic groups in the South after independence was a 'no go' area that did not fit the unified past narrative and collective memory which the teachers followed in the classroom. However, in interviews teachers were open about ethnic clashes inside the south. Certain ethnic groups were not only characterised by situational attributions, but by dispositional attributions as well. Since there was a discrepancy between what was taught and what was said in interviews in relation to ethnic tension in the south the 
teachers seemed conscious of providing a usable past in the classroom and of creating a collective memory where the interests served by the narratives, i.e. the issue of unity, were more important than historical accuracy. The attempt in the teaching, however, to create a collective memory in the south and to assign dispositional attributions to the Arabs and northerners may have been counterproductive, at least seen from the perspective of the current civil war.

A few of the teachers reported experiences with fights along ethnic lines in class. Elias (Teacher interview, 2014) mentioned an incident where a Nuer and Dinka student fought in class and how the students immediately began to mobilise to support the respective ethnic groups. Similar stories of conflicts between the two groups were narrated by other teachers. In the quotation below from an interview, the teacher attempted to ease any potential conflict in class by lecturing about the various ethnic groups in a neutral, non-conflictual way:

Then I am saying to them, if I am talking about your tribe please be relaxed. Do not become afraid. Do not take any action to anyone. Sometime I will talk about Nuer, Dinka...all the tribes of South Sudan. If I leave the class I do not want anyone to talk about the tribe of someone. That is my work only as teacher. No students has to talk to his friend and say yesterday the teacher was talking about your culture and your culture is like this and your culture is like this. That is my work and I am the one to mention every culture in South Sudan. That is not your work. Your work is only to listen. (Teacher interview, Henry 2014)

The tensions referred to by Henry underline the necessity of treating History teaching carefully and in a non-provocative way and that it should be taught by professional teachers. There is in the conflictual terrain of South Sudan a fine line between what should and should not be told even though historical 'accuracy' to some extent is being sacrificed. Clearly the teachers were afraid that discussions on sensitive topics might get out of hand and cause disciplinary problems (as indicated in the quote above) as well as problems with persons of authority, particularly in Juba. The sensitivity of tribalism and politics in general is mentioned by one of the teachers:

So here, the politics we allow them not to talk about the politics. It will be only about the war. We are not now in a peaceful country. We are in the war. The war has now taken the line of tribe. If they talk about the politics they will enter into the line of tribes later on. Later on then it will lead them now to fight and it might bring problem to the school. It is no pure politics now, it is about tribalism. (Teacher interview, Paul 2015)

The avoidance strategy employed above (see Freedman et al. 2008) is clearly an attempt to avoid conflict and perhaps to avoid cementing perceptions of dispositional attributions among southerners, but may also be due to a lack of structures for teachers to handle both personal and societal legacies of the past (Weldon 2010). In line with Weldon (2010) we argue that the teachers need to teach new attitudes and values in societies with a violent past. Without support and specific teacher training it is therefore 
very difficult, if not impossible for South Sudanese teachers to handle the narratives of violence and oppression, and they thus resort to a strategy of avoidance.

When teaching about the recent violent past one teacher argued that what is happening now (the civil war in the south after 2013) cannot be related to the past because 'in the past we were not fighting among ourselves, we were just fighting for the vision of the people of South Sudanese' (Classroom observation, Stephen 2014). Stephen highlighted the struggle of the South Sudanese against the north which unified them against a common enemy. However, his comments about the lack of tensions inside the south during the war against the north are not historically accurate even though the war against the north to some extent unified the southerners and minimised the internal ethnic tensions in the south (see e.g. Breidlid 2010). There is therefore a dilemma for the teachers when teaching about the past: it is important to reinforce the collective memory about the war against the north and thus the unified past; at the same time it is important to delink the internal civil war from the war against the Arabs in order not to disturb the one-dimensional images of the northerners and the Arabs. Moreover, while teaching about the Other in the north-south civil war is deemed safe and uncontroversial, teaching about the recent violent past is dangerous since it involves dominant ethnic groups inside the south whose differences and conflictual issues are not yet resolved. The avoidance mechanism at play here (Weldon 2010) when teaching about the recent violent past comes at a price: ignoring the recent conflict may be an attempt to minimise the consequences of the tragic recent civil war with the hope to heal differences, but the aim of producing a unified recent past comes at the expense of historical accuracy and stifles discussion and critical thinking in class.

When internal tensions are mentioned in interviews, Nilotic tribes are portrayed by some of the informants as the main ethnic groups responsible for the internal conflicts. They are described as different people with different mentalities, not well civilised and totally behind in terms of development (Interview Robert, Stephen 2014). One teacher argues that

If you can see actually any resistance that happened in history tell us actually you will find out that there was fighting that always erupt among the South Sudanese and mostly those of the Nilotic tribes. These tribes are the one, actually they have been fighting throughout... Tribes like Dinka, Anuak, Shilluk, Nuer have been fighting among themselves. (Teacher interview, John 2014)

This statement is in line with several other teachers' portrayals of Nilotic tribes, in which the two biggest ethnic groups in South Sudan, the Dinka and the Nuer, are Othered by teachers who probably come from non-Nilotic tribes. The lack of reference to the recent post-2013 conflict in the teaching might therefore be pedagogically sound (averting internal conflict in the classroom), but may also indicate a reinforcement of the domestic discourses circulating in the south, dividing Nilotic tribes from the nonNilotic tribes that are mostly agriculturalist. While the discourse is not promoted in 
class it is well-known that the discourse also existed in the war against the north, but has probably been strengthened after the outbreak of the civil war in 2013. The Othering of the Nilotes is often accompanied by attributions that are deemed dispositional; the Dinka and Nuer are often characterised by the southern Non-Nilots with innate, negative features, regularly linked to their pastoral lifestyles. Individual interviews and informal observations and conversations in the field confirmed the widespread tendency by the informants to portray the Nilotic groups differently from other ethnic groups in South Sudan. It is worth noting, however, that this Othering of the Nilots is also due to the fact that the vast majority of teacher informants were non-Nilots.

\section{Students' essays and interviews}

Only a small proportion of the 69 students' essays mention the internal conflict and civil war in the south, and very few describe the rivalry as having an explicit ethnic dimension. A few students wrote about the split in the SPLA in 1991, relating it to the liberation struggle as follows:

In 1991 the SPLA split into Torit and Nasir faction led by Dr John Garang and Riek Machar respectively. This weakened the movement. In 1992, seeing weakness in the SPLA, the Bashir government launched a military offensive...In 2002, John Garang and Riek Machar reconciled strengthening the movement once more. (Student essay, 1e)

Several students from the same class wrote about how 'the foundations of the SPLM/A was marked by internal rivalry for leadership especially between Akuot Atem and John Garang (both Twic Dinka), but in the end John Garang became the leader of the movement' (Student essay, 13e). Few of these students wrote explicitly about tribal tensions, even though the tribes of both John Garang and Riek Machar are known to all South Sudanese. However, one student clearly relates the split in 1991 to ethnic affiliation when describing the following:

The SPLA was powerful and able to defeat their enemies the Sudan Armed Forces (SAF) in the battlefield and captured almost the entire S. Sudan except three headquarters namely Wau, Malakal and Juba which where the next target of the SPLA. It was later disturbed by Dr Riek Machar and Lam Akol who defected and SPLM, SPLA (united) an attempt to overthrow on 18.08.1991 after eight years of the war. Their rebellion from the mainstream caused very destruction and atrocities. Many civilians were killed by Riek Machar forces, cattle and properties were looted by his army and their tribemen from Nuer, they were only targeting Dinka soldiers, civilian young and old were killed. This gave the Khartoum regime advantage of recapturing many towns from the SPLA. (Student essay, 6e) ${ }^{7}$

This student shows knowledge of the internal struggle within the SPLA/M in the past, including the rivalry between Dinka and Nuer leaders in the movement. The reason

7 This student is identified as a Dinka by name. 
why the Nuer are described so negatively is obviously due to the student's own ethnic affiliation with the Dinka. This one-sided narrative could have contributed to what Freedman et al. (2008) refer to as constructive conflict in class if other one-sided narratives had also been promoted. However, at this time the ethnic issue is too sensitive and possibly dangerous to bring into the classroom due to the ongoing conflicts and struggle for power among the South Sudanese elite.

\section{CONCLUSION}

This article has explored the teaching and learning of the violent past in South Sudan (1955-2005) in secondary schools and the potential of the subject of History for fostering national unity. Students that follow the Syllabus of Southern Sudan Certificate of Secondary Education (2007) learn a one-sided narrative of the recent violent past. This narrative draws an exclusively negative picture of the Arabs, northerners and Khartoum government, without mentioning structural causes of conflict or the role of southerners as active participants in the war. An interesting finding in the study is that fear of interethnic conflict prevents teachers from discussing politics and politics-related topics in class. Narratives of the current conflict and the inter-ethnic southern conflicts during the struggle for liberation lasting from 1955 up until 2005 are swept under the carpet even though the syllabus asks for discussions and descriptions of the 'causes, obstacles and effects' of armed struggles from this period (Government of Southern Sudan 2007, 173). The narratives are told using a top-down approach in an authoritarian way, presenting unquestioned narratives of the past. This discrepancy between the one-sided classroom narratives and the complex reality of civil war may from one perspective seem to limit the potential for History teaching to promote national unity in South Sudan. By exploring the limitations of these narratives in their contribution to unity, we have also identified areas of improvement such as the need for discussion and the presentation of multiple narratives in class. However, the challenges of teaching History in a newly independent country that left one war behind and started another are numerous. The aim of producing a unified recent past comes at the expense of historical accuracy and stifles discussion and critical thinking in class.

However, from another perspective the suppression of contesting narratives and the authoritarian way of teaching may signal a wish for reconciliation and that the pedagogical ideal of teaching multiple narratives may cause conflict and thus run against the wish to create unity in the classroom and in the wider society as well. There is therefore a sense that avoidance might be the best way and only alternative if these teachers are to continue teaching History in the current war situation. 


\section{REFERENCES}

Baranović, B., B. Jokić and K. Doolan. 2007. Teaching history in a postwar social contextthe case of the Croatian Danube Region. Intercultural Education 18(5): 455-71. doi:10.1080/14675980701685305

Breidlid, A. 2005. Education in the Sudan: The privileging of an Islamic discourse. Compare: $A$ Journal of Comparative Education 35(3): 247-63.

Breidlid, A. 2010. Sudanese images of the other: Education and conflict in Sudan. Comparative Education Review 54(4): 555-79. doi:10.1086/655150

Breidlid, A. 2013. Education, indigenous knowledge, and development in the Global South: Contesting knowledges for a sustainable future. New York: Routledge.

Breidlid, A, A.K. Breidlid and A.A. Said. 2014. A concise history of South Sudan: New and revised edition. Kampala: Fountain publishers.

Bryman, A. 2004. Social research methods. 2nd edition. Oxford: Oxford University Press.

Cohen, L., L. Manion and K. Morrison. 2011. Research methods in education. London: Routledge.

Cole, E.A., ed. 2007. Teaching the violent past: History education and reconciliation. Lanham: Rowman \& Littlefield Publishers.

Davies, L. 2003. Education and conflict: Complexity and chaos. 1st edition. London: Routledge.

Dorschner, J. and T. Sherlock. 2007. The role of history textbooks in shaping collective identities in India and Pakistan. In Teaching the violent past: History education and reconciliation. Edited by E.A. Cole. Lanham: Rowman \& Littlefield Publishers.

Freedman, S.W., H.M. Weinstein, K. Murphy and T. Longman. 2008. Teaching history after identitybased conflicts: The Rwanda experience. Comparative Education Review 52(4): 663-90. doi:10.1086/524046

Government of Southern Sudan. 2007. Syllabus for Southern Sudan Certificate of Secondary Education. Ministry of Education Science and Technology, Government of Southern Sudan.

Halbwachs, M. 1992. On collective memory. Chicago: University of Chicago Press.

Hammersley, M. and P. Atkinson. 1995. Ethnography: Principles and practice. 2nd edition. London: Routledge.

Heider, F. 1958. The psychology of interpersonal relations. New York: Wiley.

Heradstveit, D. 1979. The Arab-Israeli conflict: Psychological obstacles to peace. Oslo: Universitetsforlaget.

Heradstveit, D. and G.M. Bonham. 1996. Attribution theory and Arab images of the Gulf War. Political Psychology 17(2): 271. doi:10.2307/3791811

Hunt, Nigel. 2002. Review of Voices of collective remembering, by J. Wertsch. Human Nature Review 2: 528-30.

Hutchinson, S. and N. Pendle. 2015. Violence, legitimacy, and prophecy: Nuer struggles with uncertainty in South Sudan. American Ethnologist 42(3): 415-30.

Johnson, D. 2003. The root causes of Sudan's civil wars. Oxford: The International African Institute with James Curry. 
Knoblauch, H. 2005. Focused ethnography. Forum Qualitative Sozialforschung / Forum: Qualitative Social Research 6(3). Retrieved from: http://www.qualitative-research.net/index.php/fqs/article/ view/20 (accessed 21 November 2016).

Korostelina, K. 2008. History education and social identity. Identity: An International Journal of Theory and Research 8(1): 25-45. doi:10.1080/15283480701787327

McCully, A. 2009. The contribution of history teaching to peace building. In Handbook on peace education. $1^{\text {st }}$ edition. Edited by G. Salomon and E. Cairns, 213-22. New York: Psychology Press.

Millen, D.R. 2000. Rapid ethnography: Time deepening strategies for HCI field research. DIS '00 Proceedings of the 3rd conference on Designing interactive systems: Processes, practices, methods, and techniques, 280-86. doi:10.1145/347642.347763

Novelli, M., G. Daoust, J. Selby, O. Valiente, R. Scandurra, L.B. Deng Kuol and E. Salter. 2016. Exploring the linkages between education sector governance, inequality, conflict, and peacebuilding in South Sudan. Nairobi: UNICEF.

Oyenak, C. 2006. Multicultural education in support of peace in the Sudan. Oslo: Oslo University College.

Papadakis, Y. 2008. Narrative, memory and history education in divided Cyprus: A comparison of schoolbooks on the 'history of Cyprus'. History \& Memory 20(2): 128-48. doi:10.1353/ ham. 0.0008

Paulson, J. 2015. 'Whether and how?' History education about recent and ongoing conflict: A review of research. Journal on Education in Emergencies 1(1): 14-47.

Pingel, F. 2008. Can truth be negotiated? History textbook revision as a means to reconciliation. The ANNALS of the American Academy of Political and Social Science 617(1): 181-98. doi:10.1177/0002716207313087

Pink, S. and J. Morgan. 2013. Short term ethnography: Intense routes to knowing. Symbolic Interaction 36(3): 351-61.

Radio-Miraya. 2015. South Sudan to phase out foreign curriculum by 2018. Radio-Miraya. Retrieved from: http://radio-miraya.org/national/south-sudan-to-phase-out-foreign-curriculum-by-2018/ (accessed 9 July 2015).

Said, E. 1995. Orientalism. New Dehli: Penguin Books.

Skårås, M. 2016. Focused ethnographic research on teaching and learning in conflict zones: History education in South Sudan. Forum for Development Studies. doi:10.1080/08039410.2016.1202 316

Sommers, M. 2005. Islands of education. Schooling, civil war and the Southern Sudanese (1983-2004). IIEP. Retrieved from: http://www.unesco.org/iiep/PDF/pubs/sudan.pdf (accessed 15 November 2016).

Sudan Tribune. 2016a. South Sudan forms transitional government of national unity. Sudan Tribune: Plural News and Views on Sudan, 28 April. Retrieved from: http://www.sudantribune.com/spip. php?article58800 (accessed 28 April 2016).

Sudan Tribune. 2016b. S. Sudan denies ethnic killings occurred in recent clashes. Sudan Tribune: Plural News and Views on Sudan, 7 December. Retrieved from: http://www.sudantribune.com/ spip.php?article59596 (accessed 7 December 2016). 
Torsti, P. 2007. How to deal with a difficult past? History textbooks supporting enemy images in postwar Bosnia and Herzegovina. Journal of Curriculum Studies 39(1): 77-96.

Vriens, L. 2003. Responsibility for the future: The key to peace education. In Peace education in Europe: Visions and experiences. Edited by W. Wintersteiner, V. Spajic-Vrkas and R. Teutsch. Münster: Waxmann Verlag GmbH.

Weldon, G. 2010. History education and democracy in post-apartheid South Africa. The International Journal for Education Law and Policy, Special edition on Legitimation and stability of political systems. The contribution of national narratives, 88-103.

Wertsch, J.V. 2002. Voices of collective remembering. 1st edition. Cambridge University Press.

Yogev, E. 2012. The image of the 1967 War in Israeli history textbooks as test case: Studying an active past in a protracted regional conflict. Oxford Review of Education 38(2): 171-88.

Zembylas, M. and Z. Bekerman. 2008. Education and the dangerous memories of historical trauma: Narratives of pain, narratives of hope. Curriculum Inquiry 38 (2): 125-54. doi:10.1111/j.1467873X.2007.00403.x 